Ekladius, L., King, H. K. \& Sutton, C. R. (1957). J. gen. Microbiol. 17, 602-619

\title{
Decarboxylation of Neutral Amino Acids in Proteus vulgaris
}

\author{
BY L. EKLADIUS, H. K. KING AND C. R. SUTTON \\ Biochemistry Department, University of Liverpool
}

\begin{abstract}
SUMMARY : Washed suspensions and cell-free extracts of Proteus vulgaris decarboxylate leucine, valine, norvaline, isoleucine, and $\alpha$-amino- $n$-butyric acid. The system differs from most bacterial decarboxylases in being optimally active near $\mathrm{pH} 7$ and in not requiring acid conditions for its formation. The system is adaptive (inducible); the presence of either leucine, valine or isoleucine will simultaneously induce decarboxylase activity against each of the five amino acids listed above. No additive effects were found when two amino acids were offered to the system simultaneously. Pyridoxal phosphate is required as coenzyme at least for valine and leucine decarboxylation; the affinity between apo- and co-enzyme is greater during decarboxylation of valine than leucine.
\end{abstract}

Gale (1940, 1946) investigated a wide variety of bacteria (over 1000 strains) for amino acid decarboxylases. While concluding that the only common amino acids attacked were tyrosine, lysine, ornithine, arginine, histidine and glutamic acid, he also cited earlier reports that amines apparently derived from certain other amino acids had been found among the products of putrefaction. The six amino acids listed above were decarboxylated by specific enzymes with certain properties in common. Their $\mathrm{pH}$ optima lay well to the acid side of neutrality, and maximal activity was obtained only from organisms grown in relatively acid media. Proom \& Woiwod (1951) found that when Proteus spp. were grown on casein hydrolysate, paper chromatograms of the culture filtrates showed two new ninhydrin-positive substances. These were identified as isobutyl- and isoamylamines, arising from valine and leucine, respectively. Investigations in this laboratory (Papworth, 1951) showed that these amines were formed equally readily in media at $\mathrm{pH} 5 \cdot 5,7$ or $8 \cdot 5$. The decarboxylase enzymes involved did not seem to fit the pattern described by Gale (1946) and were therefore investigated in more detail. While the present work was in progress, Dewey, Hoare \& Work (1954) described the diaminopimelic acid decarboxylases of Escherichia coli and Aerobacter aerogenes, which also differ from Gale's enzymes in having neutral $\mathrm{pH}$ optima and in not requiring acid conditions for formation. The object of this study was to investigate the properties of the decarboxylase attacking valine and leucine. Preliminary reports have already appeared (King, 1953; Ekladius \& King, 1956).

\section{METHODS}

Organisms. A laboratory strain of Proteus vulgaris (no. 10 in our list) was used (except in Table 9). No other genera were examined, as Proom \& Woiwod (1951) had shown that the enzyme was confined to Proteus spp. 
Media. Nutrient broth (Lab-Lemco, $1 \%(\mathrm{w} / \mathrm{v})$; peptone, $1 \%(\mathrm{w} / \mathrm{v})$; sodium chloride, $0.5 \%(\mathrm{w} / \mathrm{v}))$, was obtained in the form of dried granules from Oxo Ltd., London. These were dissolved in the appropriate volume of tapwater and autoclaved for $20 \mathrm{~min}$. at $10 \mathrm{lb}$./sq.in. Less active suspensions were obtained when a medium containing yeast extract and casein hydrolysate was used.

Washed suspensions. The organism was maintained on nutrient agar and subcultured every 4-6 weeks. Small bottles of nutrient broth were inoculated from a slope incubated at $37^{\circ}$ for 6-8 hr. Roux bottles containing $150 \mathrm{ml}$. nutrient broth were then inoculated with a few drops of the young broth culture, and harvested after $15 \mathrm{hr}$. incubation at $37^{\circ}$. The organisms were washed twice on the centrifuge with distilled water, and then suspended in a suitable volume of buffer $(0 \cdot 2 \mathrm{M}$-phosphate, $\mathrm{pH} 6)$. The density of the suspension was determined turbidimetrically; the instrument was calibrated against suspensions whose dry weight had been determined by freeze-drying. The $\mathrm{CO}_{2}$ output of washed suspensions in the absence of added substrate was usually negligible $\left(Q_{\mathrm{CO}_{2}}<1\right)$.

Freeze-dried organisms were prepared by placing a washed suspension (suspended in water) in a small evaporating basin in a vacuum desiccator over sulphuric acid. The desiccator was evacuated until boiling followed by freezing took place, and the pressure was then reduced to $0 \cdot 1 \mathrm{~mm}$. $\mathrm{Hg}$. These preparations remained active after several months' storage at $-10^{\circ}$, but required addition of coenzyme for full activity (see Table 10). They provided a convenient means of storing material.

Cell-free extracts were prepared from fresh or freeze-dried organisms either by shaking with glass beads (Ballotini no. 12; King \& Alexander, 1948) or by grinding with fine aluminium oxide (McIlwain, 1948). The alumina method consistently gave extracts of about the same activity as intact organisms. The ballotini extraction gave variable results since this treatment, when prolonged, tended to inactivate the enzyme. By shaking for $45 \mathrm{~min}$. at 400500 strokes/min. $(2 \cdot 5$ in. stroke) it was usually possible to obtain extracts somewhat more active than the original organisms. Extracts prepared by either method were used the same day since appreciable inactivation took place on storage at $0^{\circ}$ for $24 \mathrm{hr}$., although about one-fifth of the activity survived even after three weeks.

Reagents. Amino acids were from commercial sources and were examined by paper chromatography before use. Many samples of L-leucine contained valine and alanine but chromatographically pure material was obtained from Roche Products, Ltd. The $\mathrm{L}$ isomers were used except where otherwise indicated; DL amino acids were used where the L-compounds were not available and in some confirmatory experiments, since the synthetic racemate was less likely to be contaminated with other natural amino acids than the commercial $\mathrm{L}$ isomer isolated from protein hydrolysates. The pyridoxal phosphate used was a generous gift from Messrs Roche Products Ltd., through the courtesy of Dr A. L. Morrison. The solutions were stored at $0^{\circ}$, protected from light at all times, and discarded after 4 weeks. 
Buffers used. These were: $\mathrm{pH} 4 \cdot 5-5 \cdot 5$, potassium hydrogen phthalate + sodium hydroxide, containing $0.1 \mathrm{M}$-phthalate; $\mathrm{pH} \mathrm{6-8}$, potassium dihydrogen phosphate +disodium hydrogen phosphate, containing $0.2 \mathrm{M}$-phosphate; pH 8.5-10, boric acid + sodium hydroxide, borate concentration $0 \cdot 1 \mathrm{M}$.

Manometry. Except where otherwise stated, nitrogen-filled Warburg manometers were used at $37^{\circ}$ and $\mathrm{pH}$ 6. This is not the optimum $\mathrm{pH}$ value for the enzyme, but was selected to permit direct observation of the course of the reaction since at this $\mathrm{pH}$ value $\mathrm{CO}_{2}$ retention is small. The main compartment of the manometer flasks contained the equivalent of 15-30 mg. dry wt. organisms (or the corresponding amount of cell-free preparations), buffer, $(\mathrm{pH} \mathrm{6,} 0.2 \mathrm{M})$ and any other additions (e.g. coenzyme) in a total volume of $2 \mathrm{ml}$. The side-bulb contained the amino acid (final concentration $0.08 \mathrm{M}$ of $\mathrm{L}$ isomer in most cases) dissolved in $1 \mathrm{ml}$. buffer. At $\mathrm{pH}$ values greater than $\mathrm{pH} 6,0 \cdot 25 \mathrm{ml}$. $2 \mathrm{~N}-\mathrm{HCl}$ was placed in a second side-bulb; manometers were set up in pairs consisting of an 'experiment' flask in which the substrate was added at the beginning of the experimental period and the acid at the end, and a 'control 'flask in which both acid and substrate were added at the end of the run. $Q_{\mathrm{Co}_{3}}^{\mathrm{N}}$ values were calculated over a period of $30 \mathrm{~min}$. from addition of substrate. $\mathrm{CO}_{2}$ output was linear except for leucine decarboxylation without added coenzyme (cf. Fig. 4, curve I): in this case $\boldsymbol{Q}_{\mathrm{CO}_{2}}$ was calculated from the steady rate attained after c. $10 \mathrm{~min}$.

Addition of coenzyme. Even in intact organisms the rate of leucine decarboxylation is limited by the amount of coenzyme available (see below). Most experiments-whether with leucine or other amino acids-were performed in the presence of sufficient coenzyme to saturate the system. In most cases pyridoxal, rather than pyridoxal phosphate, was used for reasons of economy; but the nature and amount of coenzyme added is stated in each experiment.

Analytical methods. Descending single-dimensional paper chromatography was carried out with the solvent butanol $(480 \mathrm{ml}$. $)$ +acetic acid $(95 \mathrm{ml})+$. butyl acetate $(35 \mathrm{ml})+$. water $(195 \mathrm{ml}$.$) ; amino acids and amines give blue$ spots on spraying with ninhydrin $(0.1 \%$, in chloroform with $0.1 \%$ collidine).

Ammonia was determined according to Conway (1947). When ammonia and amines were present together, the amines were determined by the colorimetric method of Ekladius \& King (1957) and the ammonia estimated by subtracting this value from the total volatile base determined by Conway's (1947) method.

\section{RESULTS}

\section{Metabolism of amino acids by Proteus vulgaris}

In air, each of 18 amino acids tested was rapidly oxidized $\left(Q_{\mathrm{Co}_{2}}^{\mathrm{N}}\right.$, values ranging from 50 to 250) by washed suspensions of Proteus vulgaris (strain 10). Bernheim, Bernheim \& Webster (1935) and Stumpf \& Green (1944) reported a very active L-amino acid oxidase in Proteus spp. In nitrogen in presence of $10^{-4} \mathrm{M}$ pyridoxal no appreciable gas evolution was obtained with DL-alanine, glycine, L-glutamic acid, L-arginine, L-histidine, L-lysine, DL-ornithine, L-proline, L-tyrosine or L-tryptophane. L-Leucine, L-isoleucine and L-valine were de- 
carboxylated and this is discussed in detail in this paper. A few other amino acids, viz. L-aspartic acid (cf. Meister, Sober \& Tice, 1951); DL-serine (cf. Chargaff \& Sprinson, 1943) and L-cystine (cf. Tarr, 1933; Kallio \& Porter, 1950), yielded carbon dioxide. Ammonia was a major product in these cases; the reactions could not therefore, be simple decarboxylations, and lie outside the main theme of this paper.

Most of the known bacterial decarboxylases have acid pH optima and are formed only in markedly acid media (Gale, 1940, 1946). Decarboxylases of this type, specific for glutamic acid and ornithine, have been reported in Proteus spp. (Gale, 1941). A search for this type of enzyme was made in organisms grown for $18 \mathrm{hr}$. at $37^{\circ}$ in nutrient broth containing $1 \%$ glucose but these did not yield carbon dioxide when tested at $\mathrm{pH} 4.5$ with any of the 18 amino acids examined (cf. Gale, 1940). The organism does, however, possess an ornithine decarboxylase, preferentially formed in acid media and optimally active at pH 6 (Table 7, Fig. 1).

\section{Decarboxylation of neutral amino acids}

The rates of decarboxylation of various amino acids are shown in Table 1 . $D$-Valine and $D$-leucine are not attacked, neither do they inhibit the decarboxylation of the L-isomers. L-Alanine and DL- $\alpha$-amino-iso-butyric acid serve neither as substrates nor as inhibitors. When two substrates were added simultaneously no significant additive effects were observed (Table 1; see also Figs. $6 a, 7 a$ ). Similar results were obtained with intact organisms. Phenylalanine was decarboxylated too slowly for additive effects to be demonstrated.

Table 1. Decarboxylation of amino acids by cell-free extracts of Proteus vulgaris

\begin{tabular}{|c|c|c|c|}
\hline Substrate & $Q_{\mathrm{CO}}^{\mathrm{N}}$, & Substrate & $Q_{\mathrm{c} \delta}^{\mathbb{N} z}$, \\
\hline L-Valine & 19 & Valine + leucine & 17 \\
\hline DL-Leucine & 19 & Valine $+\alpha$-amino butyric acid & 17 \\
\hline DL-Norvaline & 13 & Valine + isoleucine & 17 \\
\hline DL-Isoleucine & 11 & Valine + norvaline & 17 \\
\hline DL- $\alpha$-amino- $n$-butyric acid & 6 & Leucine + norvaline & 20 \\
\hline DL-Phenylalanine & 1.5 & Isoleucine + norvaline & 16 \\
\hline Control (no substrates) & $\mathbf{0}$ & $\alpha$-Aminobutyric acid + norvaline & 8 \\
\hline
\end{tabular}

Final concentrations of amino acids, $0.05 \mathrm{M}$ : of pyridoxal phosphate, $1.3 \times 10^{-5} \mathrm{M}$.

\section{Products of decarboxylation}

The amines were provisionally identified by paper chromatography (Proom \& Woiwod, 1951; Bremner \& Kenten, 1951). Confirmation was obtained by isolation of the crystalline $p$-toluene sulphonamide derivatives.

isoButylamine from valine. A large-scale washed-suspension experiment was carried out in two $250 \mathrm{ml}$. Erlenmeyer flasks carrying fittings for filling with nitrogen. Each flask contained $1.5 \mathrm{~g}$. DL-valine and $\mathbf{0 . 9} \mathrm{mg}$. pyridoxal hydrochloride in $80 \mathrm{ml}$. of $0.2 \mathrm{M}$-phosphate buffer ( $\mathrm{pH} \mathrm{6}$ ). The suspension of Proteus vulgaris (750 mg. dry wt. in $18 \mathrm{ml}$.) was placed in the flask in a separate tube suspended by a thread. The flasks were filled with nitrogen and the suspension 
added to the substrate by tipping the flasks, which were then gently shaken at $37^{\circ}$. The reaction was stopped after $2.5 \mathrm{hr}$. by adding $2 \mathrm{~N}-\mathrm{HCl}$ till acid to litmus, the organisms removed by centrifugation, and the supernatant fluid made alkaline (excess $\mathrm{NaOH}$ ) and distilled into $20 \mathrm{ml} .0 \cdot 1 \mathrm{~N}-\mathrm{HCl}$. The distillate was made alkaline and extracted with ether $(3 \times 30 \mathrm{ml}$.). The ether extract was washed once with water, then acidified with a few drops of $2 \mathrm{~N}-\mathrm{HCl}$ and the ether distilled off. The residue was treated with $1 \mathrm{~g}$. $p$-toluene sulphonyl chloride and $10 \% \mathrm{NaOH}$ added gradually, with vigorous shaking. After addition of $20 \mathrm{ml}$. the mixture (now strongly alkaline) was gently heated on the water bath to decompose excess $p$-toluene sulphonyl chloride. On acidification to $\mathrm{pH} 3$ with $2 \mathrm{~N}-\mathrm{HCl}$, a bulky precipitate of $\mathrm{N}$-isobutyltoluene- $p$-sulphonamide was formed. This was filtered off, washed with water, sucked dry, and dissolved in $1 \mathrm{ml}$. benzene on a steam bath. Light petroleum (b.p. 40-60 ${ }^{\circ}$ ) was added until a slight turbidity was observed; the solution was filtered and left overnight in the refrigerator. The bulky mass of crystals which separated out was filtered off and dried in vacuo. Weight, $202 \mathrm{mg}$.; a yield of $220 \mathrm{mg}$. had been expected from the carbon-dioxide output, which had been measured separately in a parallel experiment in a Warburg manometer. The identity of the derivative was confirmed by determination of melting-point; by mixed melting-point with a sample prepared from authentic isobutylamine; and by nitrogen determination (Kjeldahl).

Table 2. Characterization of amines as $\mathrm{p}$-toluene sulphonamides

\begin{tabular}{|c|c|c|c|c|c|}
\hline \multirow[b]{2}{*}{ Amino acid } & \multirow[b]{2}{*}{ Amine } & \multirow{2}{*}{$\begin{array}{l}\text { M.p. } \\
\text { found } \\
\left(^{\circ}\right)\end{array}$} & \multirow{2}{*}{$\begin{array}{c}\text { M.p. } \\
\text { reference } \\
\left({ }^{\circ}\right)\end{array}$} & \multicolumn{2}{|c|}{ N (Kjeldahl) (\%) } \\
\hline & & & & Found & Calc. \\
\hline Norvaline & $n$-Butylamine & 43 & $43 *(1)$ & $6 \cdot 19$ & $6 \cdot 18$ \\
\hline Valine & iso-Butylamine & 78 & $78+(2)$ & $6 \cdot 16$ & $6 \cdot 18$ \\
\hline Leucine & iso-Amylamine & 65 & $65 \ddagger(3)$ & $5 \cdot 72$ & $5 \cdot 81$ \\
\hline Isoleucine & 3-Methylbutylamine & 38 & - & $5 \cdot 76$ & $5 \cdot 81$ \\
\hline Phenylalanine & 2-Phenylethylamine & 64 & $65-66 \S(4)$ & $5 \cdot 10$ & $5 \cdot 09$ \\
\hline $\begin{array}{l}\alpha \text {-Amino- } n \text { - } \\
\text { butyric acid }\end{array}$ & $n$-Propylamine & 52 & $52 \|(5)$ & $6 \cdot 61$ & $6 \cdot 57$ \\
\hline
\end{tabular}

The other amines were similarly identified (see Table 2). As no authentic sample of $\beta$-methylbutylamine (from isoleucine) was available and we could find no recorded m.p. for this compound in the literature, confirmation was obtained by elementary analysis of the $p$-toluene sulphonamide derivative (Drs Weiler and Strauss, Oxford). Found: C, 60.0\% $\mathbf{H}, \mathbf{7} \cdot 88 \% ; \mathrm{S}, \mathbf{1 3 . 0} \%$, $\mathrm{N}, 5 \cdot 76 \%$. Calculated $\left(\mathrm{C}_{12} \mathrm{H}_{18} \mathrm{NSO}_{2}\right), \mathrm{C} 59 \cdot 8 \% ; \mathrm{H}, 7 \cdot 88 \%, \mathrm{~S}, 13 \cdot 3 \%, \mathrm{~N}, 5 \cdot 80 \%$. An attempt was also made to characterize the amines by condensation with phenylisothiocyanate to give the corresponding alkyl-phenyl-thiourea. This was successful only in the case of isoamylamine (from leucine). The derivative was prepared and its identity confirmed (m.p. $102^{\circ}$ ); no depression on mixing with sample of derivative prepared from authentic isoamylamine; $\mathbf{N}$ found, $12 \cdot 6 \%$, calculated, $12 \cdot 6 \%$. Willard \& Jones (1940) give the m.p. 101-102 ${ }^{\circ}$. 
Amine and carbon dioxide are produced in approximately equimolar amounts, without any appreciable production of ammonia (Table 3). Phenylethylamine production from phenylalanine was not investigated quantitatively as the amine production was too small for accurate estimation.

Table 3. Production of amines and carbon dioxide from amino acids by Proteus vulgaris strain 10

\begin{tabular}{lcccc} 
& \multicolumn{3}{c}{ Amine $(\mu$ mole $)$} & \\
DL- $\alpha$-Amino- $n$-butyric acid & $\overbrace{\text { Expt. }}$ & Control & Diff. & CO $_{2}(\mu$ mole $)$ \\
L-Isoleucine & $\mathbf{3 4}$ & $\mathbf{3}$ & $\mathbf{3 1}$ & $\mathbf{2 9}$ \\
L-Leucine & $\mathbf{9 4}$ & $\mathbf{3}$ & $\mathbf{9 1}$ & $\mathbf{9 0}$ \\
L-Valine & 60 & $\mathbf{3}$ & $\mathbf{5 7}$ & 61 \\
DL-Norvaline & $\mathbf{9 0}$ & $\mathbf{3}$ & $\mathbf{8 7}$ & $\mathbf{8 8}$ \\
& 49 & $\mathbf{3}$ & $\mathbf{4 6}$ & $\mathbf{5 2}$
\end{tabular}

Manometers contained: (main flask), $32 \mathrm{mg}$. organism in $2 \mathrm{ml}$. buffer, $\mathrm{pH} \mathrm{6}$, with $10^{-4} \mathrm{M}$ pyridoxal phosphate; (side bulb 1 ), $1 \mathrm{ml}$. amino acid $(0.125 \mathrm{M}$-leucine, isoleucine, valine; $0.25 \mathrm{M}$-norvaline, aminobutyric acid); (side-bulb 2), $0.25 \mathrm{ml} .2 \mathrm{~N}-\mathrm{HCl}$. In experimental manometers, side-bulb 1 tipped at $t=0$, side bulb 2 at $t+90$ min. In controls, both side bulbs tipped at $t=90 \mathrm{~min}$. All manometers set up in triplicate, contents pooled at end of experiment, cells removed by centrifugation, and amine determined. No significant amounts of ammonia found in any case.

\section{Factors influencing enzyme activity}

Effect of $\mathrm{pH}$ value. The $\mathrm{pH}$-activity curves for the decarboxylation of valine, leucine and isoleucine are shown in Fig. 1. Excess pyridoxal $\left(10^{-4} \mathbf{M}\right)$ was added in each case; but experiments without added coenzyme gave similar curves. Certain precautions were necessary in determining the curve for leucine. Even in the presence of excess coenzyme, $\mathrm{CO}_{2}$ output is sometimes more rapid in the first few minutes than later. The $Q_{\mathrm{Co}_{2}}^{\mathrm{N}_{2}}$ values were therefore calculated over the period 20-50 min. after addition of the leucine. At the $\mathrm{pH}$ values above 6, leucine was tipped in both experimental and control flasks at $t=0$, and the acid was added to stop the reaction and expel the $\mathrm{CO}_{2}$ at $t=20 \mathrm{~min}$. in the controls and at $t=50 \mathrm{~min}$. in the experimental manometers. To ensure that output was linear over this period at the higher $\mathrm{pH}$ values, the course of the reaction was followed at $\mathrm{pH} \mathbf{8 . 5}$ by setting up a series of manometers in which the acid was added at varying times after addition of the leucine. No excessive initial output of $\mathrm{CO}_{2}$ was found. For comparison, the curve for the ornithine decarboxylase is included. In a number of strains of Proteus, Gale (1941) found this enzyme to be optimally active at $\mathrm{pH} 5 \cdot 5$, rather lower than our figure of $6 \cdot 5$.

Substrate concentration. The Michaelis constants $\left(K_{s}\right)$ for the decarboxylation of leucine, norvaline, and $a$-amino- $n$-butyric acids by cell-free extracts in the presence of $2 \times 10^{-5} \mathrm{M}$ pyridoxal phosphate was $10^{-2} \mathrm{M}$ in each case; for valine, a value of $2.5 \times 10^{-2} \mathrm{M}$ was obtained. (Experimental data supplied by Miss B. Haughton.) For intact organisms the values were $10^{-2} \mathbf{M}$ for leucine and $3.3 \times 10^{-2} \mathrm{M}$ for valine (no coenzyme added).

Temperature effect. The effect of temperature is shown in Table 4. At $40^{\circ}$ the rate of decarboxylation of both amino acids begins to decrease significantly 
after about $12 \mathrm{~min}$. and the $Q$ values at this temperature were calculated from the initial reaction velocity. At the lower temperatures, the reaction was linear for at least $60 \mathrm{~min}$.
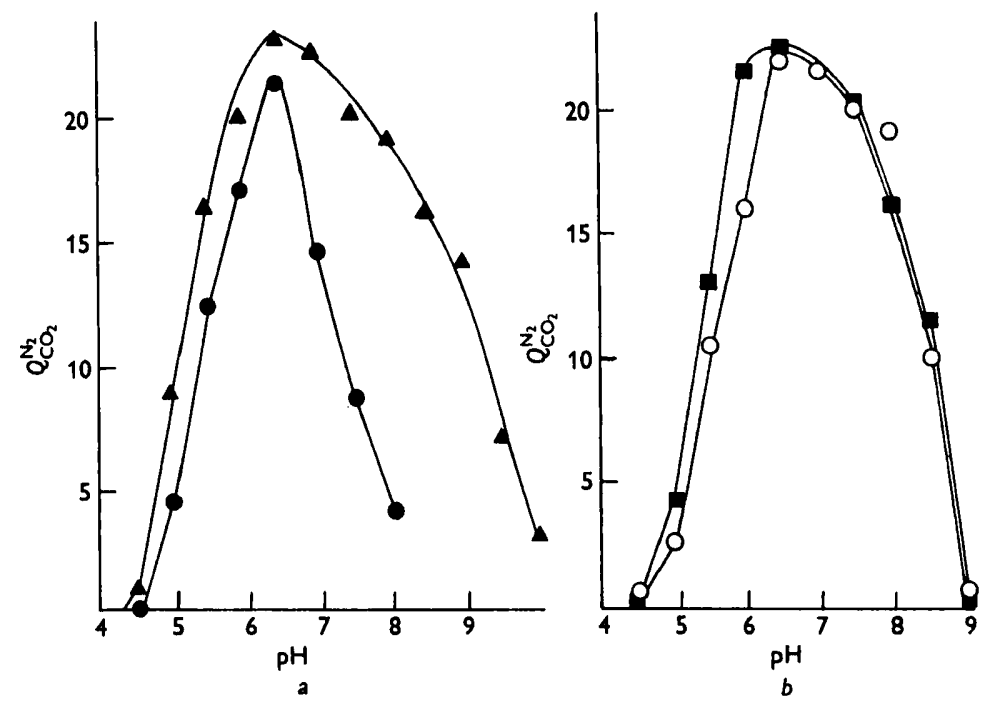

Fig. 1. pH-activity curves of decarboxylation by intact cells. $a, \Delta-\Delta$, valine; ornithine: $b,-\square$, isoleucine; $\bigcirc-\bigcirc$, leucine. All measurements (except ornithine) performed in presence of $10^{-4} \mathrm{M}$ pyridoxal. Final concentration of amino acids, $0.08 \mathrm{M}$. $Q_{\mathrm{CO}}^{\mathrm{N}}$, measured over $30 \mathrm{~min}$. at $37^{\circ}$ in nitrogen.

Table 4. Influence of temperature on decarboxylation of valine and leucine by washed suspensions of organism

\begin{tabular}{|c|c|c|c|}
\hline $\begin{array}{c}\text { Temp. } \\
\left({ }^{\circ}\right)\end{array}$ & $Q_{\mathrm{CO}}^{\mathrm{N}_{2}}$, [valine] & $Q_{10}$ & $Q_{\mathbf{C} \mathbf{S}_{2}}^{\mathrm{N}}$ [leucine] \\
\hline 13 & 1.3 & - & $2 \cdot 2$ \\
\hline 20 & $2 \cdot 8\}$ & $4 \cdot 1$ & $2 \cdot 8\}$ \\
\hline 30 & $11.5\}$ & 3.8 & $9 \cdot 7\}$ \\
\hline 40 & $43.5\}$ & & $36 \cdot 3\}$ \\
\hline
\end{tabular}

All experiments carried out in presence of $10^{-4} \mathrm{M}$-pyridoxal.

Inhibitors. The action of a number of inhibitors is shown in Table 5. Two observations call for comment. (1) The decarboxylations were highly sensitive to reagents known to react with - SH groups, viz. iodoacetate, $p$-chlormercuribenzoate and mercuric chloride. (2) Decarboxylation of leucine was more sensitive than valine decarboxylation to semicarbazide and hydroxylamine, reagents known to combine with carbonyl groups. This is discussed later. Otherwise, the different decarboxylations show a fairly uniform response to any given agent.

Presence of oxygen. The effect of aeration on decarboxylation cannot be determined directly by manometery since the very rapid oxygen uptake would mask the gas output arising from decarboxylation. Amine production was 
Table 5. Sensitivity of decarboxylation to various agents

Washed suspensions (WS) or cell-free extracts (CF) were exposed to the specific agent for $15 \mathrm{~min}$. at $37^{\circ}$ (unless otherwise indicated) and $Q_{\mathrm{C} \delta}^{\mathrm{N}}$, determined. Pyridoxal phosphate $\left(2 \times 10^{-5} \mathrm{M}\right)$ added in cell-free extract experiments only.

\begin{tabular}{|c|c|c|c|c|c|c|}
\hline \multirow[b]{2}{*}{ Agent } & \multicolumn{6}{|c|}{ Percentage inhibition of decarboxylation } \\
\hline & $\begin{array}{l}\text { Enzyme } \\
\text { source }\end{array}$ & Leucine & Valine & $\begin{array}{l}\text { Nor- } \\
\text { valine }\end{array}$ & $\begin{array}{c}\text { Iso- } \\
\text { leucine }\end{array}$ & $\begin{array}{l}\alpha \text {-Amino- } \\
n \text {-butyric } \\
\text { acid }\end{array}$ \\
\hline Iodoacetate $\left(10^{-3} \mathrm{M}\right)$ & CF & 45 & 30 & $\mathbf{3 5}$ & 40 & $\mathbf{5 5}$ \\
\hline Mercuric chloride $\left(10^{-4} \mathrm{M}\right)$ & WS & 100 & 100 & - & - & 一 \\
\hline Mercuric chloride $\left(10^{-5} \mathrm{M}\right)$ & WS & 10 & 10 & - & - & - \\
\hline Silver nitrate $\left(10^{-2} \mathrm{M}\right)$ & WS & 100 & 100 & 一 & 一 & - \\
\hline Silver nitrate $\left(10^{-3} \mathrm{M}\right)$ & WS & $\mathbf{5 5}$ & $\mathbf{5 5}$ & - & - & - \\
\hline$p$-Chlormercuribenzoate $\left(10^{-6} \mathrm{M}\right)$ & CF & 10 & 30 & 35 & $\mathbf{3 0}$ & 35 \\
\hline 8-Hydroxyquinoline $\left(10^{2} \mathrm{M}\right)$ & WS & $\mathbf{5 5}$ & $\mathbf{5 5}$ & - & - & - \\
\hline Potassium cyanide $\left(10^{-3} \mathrm{M}\right)$ & WS & 80 & 80 & 一 & - & - \\
\hline Hydroxylamine $\left(10^{-8} \mathrm{M}\right)$ & WS & 100 & 90 & - & - & - \\
\hline Hydroxylamine $\left(10^{-3} \mathrm{M}\right)$ & WS & 41 & $\mathbf{0}$ & - & 一 & - \\
\hline Semicarbazide $\left(10^{-3} \mathrm{M}\right)$ & CF & 90 & 33 & 84 & 84 & 90 \\
\hline Semicarbazide $\left(10^{-3} \mathrm{M}\right)$ & WS & 90 & 55 & - & - & - \\
\hline Ethanol $25 \%(v / v)$ for $5 \mathrm{~min} .(a)$ & WS & 25 & $\mathbf{0}$ & - & - & 一 \\
\hline Ethanol $50 \%(\mathrm{v} / \mathrm{v})$ for $5 \mathrm{~min} .(a)$ & WS & 100 & 100 & - & 一 & - \\
\hline $\begin{array}{l}\text { Potassium hydrogen phthalate } \\
(0 \cdot 1 \mathrm{~m}) \text { for } 10 \mathrm{~min} .(a)\end{array}$ & WS & 100 & 100 & - & - & 一 \\
\hline $\mathrm{Na}_{2} \mathrm{CO}_{3}(0.1 \mathrm{M})$ for $10 \mathrm{~min} .(a)$ & WS & 15 & 33 & 一 & - & - \\
\hline Heating at $60^{\circ}$ for $10 \mathrm{~min}$. & CF & 65 & 70 & 65 & 70 & 80 \\
\hline Storage at $0^{\circ}$ for 3 weeks & CF & 80 & 80 & 80 & 80 & $\mathbf{8 5}$ \\
\hline
\end{tabular}

(a) Organisms centrifuged down after exposure, washed and resuspended in pH 6 buffer.

therefore used as a measure of decarboxylation. Valine and leucine were decarboxylated by washed organisms at $\mathrm{pH} 7$ both in nitrogen-filled, and in air-filled manometers with $\mathrm{KOH}$ in the centre cup. The oxygen uptake was measured in the latter case to ensure that the substrates were not exhausted before the end of the experiment. The reaction was stopped after $60 \mathrm{~min}$. by addition of acid, the organisms removed by centrifugation, and the amine in the supernatant fluids estimated. The results (Table 6) showed that decarboxylation was retarded under conditions of good aeration.

Table 6. Effect of aeration on amine formation

\begin{tabular}{lcc} 
& \multicolumn{2}{c}{ Amine formed $(\mu$ mole $)$} \\
\cline { 2 - 3 } Substrate & Aerobic & Anaerobic \\
Valine & 16.5 & 28.5 \\
Leucine & 4.5 & 10.8 \\
None & 0.0 & 0.0
\end{tabular}

Washed suspensions allowed to act on leucine or valine in presence of air or of nitrogen at $\mathrm{pH} 7$; acid added at end of experiment, the organisms removed and amine estimated. Duration of experiment, $60 \mathrm{~min}$. Final concentrations; valine, $0.16 \mathrm{M}$, leucine, $0.08 \mathrm{M}$. No coenzyme added. 
Factors affecting formation of the enzyme

Age of culture. Valine decarboxylation proceeded rapidly in young cultures but fell to a low value when active growth ceased (Fig. 2). The older cultures also showed large endogenous carbon dioxide production.

$\mathrm{pH}$ value during growth. Washed suspensions were made from organisms grown on nutrient broth buffered with phosphate at $\mathrm{pH} 5.5(0.1 \mathrm{M}), \mathrm{pH} \mathrm{6.5}$, 7.5 and $8.5(0.05 \mathrm{M})$. These buffers kept the $\mathrm{pH}$ value fairly constant during growth (see Table 7 ). The growth rate did not vary appreciably over this

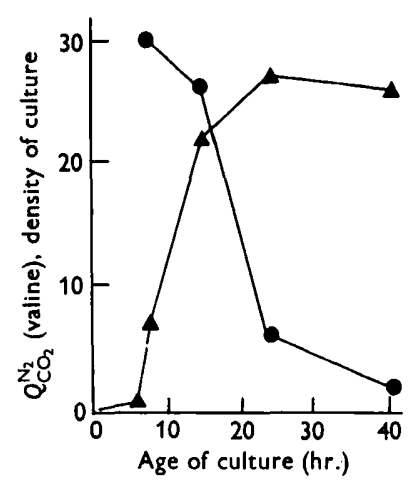

Fig. 2

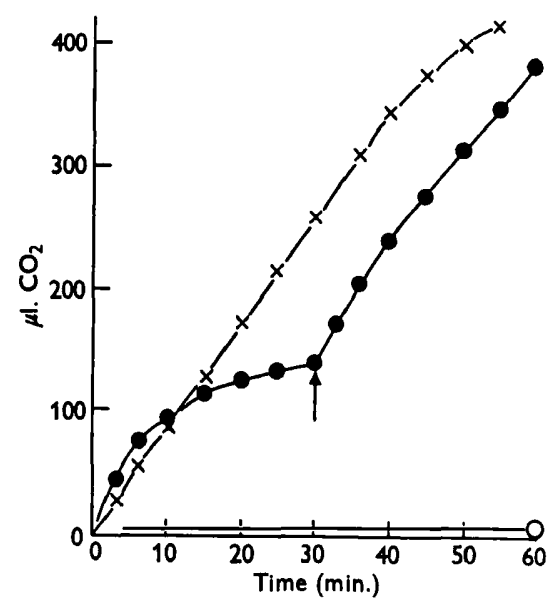

Fig. 3

Fig. 2. Effect of age of culture on valine decarboxylase activity. Organisms grown on nutrient broth at $37^{\circ}$ for the time specified, and the growth estimated turbidimetrically washed suspensions prepared and $Q_{\mathrm{CO}_{3}}^{\mathrm{N}_{3}}$ determined under standard conditions with valine (final concentration $0.08 \mathrm{M}$ ) as substrate.,$- Q_{\mathrm{CO}}^{\mathrm{N}}$ (valine); $\Delta-\Delta$, culture density (nephelometer readings).

Fig. 3. Effect of pyridoxal phosphate on decarboxylation of leucine. Manometers contained washed suspension (35 mg. dry wt.) in main flask. Valine $(0.04 \mathrm{M})$ added at $t=0$, $\times-\times$; leucine $(0.04 \mathrm{M})$ at $t=0$, pyridoxal $\left(10^{-4} \mathrm{M}\right)$ at $t=30 \mathrm{~min}$., - ; no-substrate control, $\mathrm{O}-\mathrm{O}$.

Table 7. Effect of $\mathrm{pH}$ value during growth on development $\mathrm{pH}$ value of medium

$$
\text { of decarboxylase activity }
$$

\begin{tabular}{|c|c|c|c|c|}
\hline Initial & Final & $Q_{\mathrm{CO}}^{\mathrm{N}}$, (ornithine) & $Q_{\mathrm{CO}_{2}}^{\mathrm{N}_{2}}$ (leucine) & $Q_{\mathrm{CO}_{\mathrm{a}}}^{\mathrm{Na}_{3}}$ (valine) \\
\hline (See legend) & $4 \cdot 5$ & $16 \cdot 2$ & $2 \cdot 1$ & $2 \cdot 1$ \\
\hline $5 \cdot 5$ & $5 \cdot 8$ & $8 \cdot 5$ & 4.7 & $4 \cdot 1$ \\
\hline 6.5 & $6 \cdot 8$ & $2 \cdot 4$ & 4.8 & $3 \cdot 4$ \\
\hline $7 \cdot 5$ & $7 \cdot 6$ & $\mathbf{1}$ & $5 \cdot 7$ & $5 \cdot 7$ \\
\hline $8 \cdot 5$ & 8.5 & 1 & $3 \cdot 8$ & $2 \cdot 5$ \\
\hline
\end{tabular}

Organisms were grown in broth buffered to the pH indicated in col. 1, and harvested after $18 \mathrm{hr}$. at $37^{\circ}$ and washed suspensions prepared. In the first line, unbuffered broth (pH 7) containing $1 \%$ glucose was used, the $\mathrm{pH}$ value falling to 4.5 during growth. The $Q_{\mathrm{CO}}^{\mathrm{N}_{2}}$ values were determined over a $90 \mathrm{~min}$. period at $\mathrm{pH} 7$; no coenzyme was added; amino acids at $0.02 \mathrm{M}$ final concentration. 


\section{Amino acid decarboxylation in $\mathrm{P}$. vulgaris}

range; though at higher or lower $\mathrm{pH}$ values it declined sharply. The ' $\mathrm{pH} \mathrm{4.5}$ ' results were obtained from organisms grown for $18 \mathrm{hr}$. at $37^{\circ}$ in unbuffered nutrient broth containing $1 \%$ glucose; the $\mathrm{pH}$ value fell to 4.5 during growth. It was not possible to initiate growth at this $\mathrm{pH}$ value. Both valine and leucine decarboxylation remained fairly constant save at the extremes of the range; ornithine decarboxylase forms a sharp contrast, being preferentially formed in acid media and thus conforming to the pattern described by Gale (1940, 1946).

Temperature. Some decarboxylases are preferentially formed at temperatures below $37^{\circ}$ (Gale, 1940). No increase in activity was obtained however when the organisms were grown for $24 \mathrm{hr}$. at $30^{\circ}$ instead of the usual $15 \mathrm{hr}$. at $37^{\circ}$.

Table 8. Relation between decarboxylase activity and presence of amino acid in the medium during growth

\begin{tabular}{|c|c|c|c|c|c|c|}
\hline \multirow[b]{2}{*}{$\begin{array}{c}\text { Amino acid } \\
\text { added to medium }\end{array}$} & \multicolumn{6}{|c|}{$Q_{\mathrm{CO}}^{\mathrm{N}}$, when decarboxylating } \\
\hline & Leucine & Valine & $\begin{array}{l}\text { Nor- } \\
\text { valine }\end{array}$ & $\begin{array}{c}\text { Iso- } \\
\text { leucine }\end{array}$ & $\begin{array}{c}\text { Amino- } \\
\text { butyric } \\
\text { acid }\end{array}$ & $\begin{array}{l}\text { No } \\
\text { substrate }\end{array}$ \\
\hline None & 2 & $\mathbf{2}$ & $\mathbf{1}$ & $\mathbf{0}$ & $\mathbf{0}$ & $\mathbf{0}$ \\
\hline L-Leucine & 29 & 19 & 17 & 14 & 12 & $\mathbf{0}$ \\
\hline DL-Valine & 13 & 9 & 8 & $7 \cdot 5$ & $\mathbf{5}$ & $\mathbf{0}$ \\
\hline DL-Norvaline & 6 & 3 & 3 & $\mathbf{3}$ & 1.5 & $\mathbf{0}$ \\
\hline DL-Isoleucine & 9 & 7 & 7 & $\mathbf{5}$ & 3.5 & $\mathbf{0}$ \\
\hline DL-Aminobutyric acid & 3 & 2 & $\mathbf{1}$ & 2 & - & $\mathbf{0}$ \\
\hline $\begin{array}{l}\text { Organisms grown on } \\
\text { broth }\end{array}$ & 37 & 24 & 23 & 18 & 13 & $\mathbf{0}$ \\
\hline
\end{tabular}

Organisms were grown on defined medium with lactate as sole carbon source for $16 \mathrm{hr}$., and the amino acid indicated was added to give a concentration of $0.05 \mathrm{M}$ of $\mathrm{L}$-isomer. Incubation was continued for further $3.5 \mathrm{hr}$, cell-free extracts prepared and decarboxylase activity was then determined in presence of $1.3 \times 10^{-5} \mathrm{M}$-pyridoxal phosphate.

Medium. Cell-free extracts prepared from organisms grown on a defined medium showed only slight activity (Table 8 ). The medium used contained $\left(\mathrm{NH}_{4}\right)_{2} \mathrm{SO}_{4}, \mathbf{0} \cdot 8 \%$ (w/v); $\mathrm{NaCl}, 0.5 \%$ (w/v); $\mathrm{KH}_{2} \mathrm{PO}_{4}, \mathbf{0 . 2} \%$ (w/v); $\mathrm{Na}_{2} \mathrm{HPO}_{4}$, $0 \cdot 2 \%(\mathrm{w} / \mathrm{v})$; nicotinamide $1: 200,000$; sodium lactate, $0 \cdot 8 \%(\mathrm{w} / \mathrm{v})$ in tap water. The effect of certain amino acids in stimulating enzyme formation was examined as follows. Organisms were grown for $16 \mathrm{hr}$. at $37^{\circ}$ on the defined medium, the inoculum being prepared from a culture of Proteus vulgaris (strain 10) maintained on this medium. The amino acid under test was then added (final concentration $0.05 \mathrm{M}$ of L-isomer). After incubation for a further period of $3.5 \mathrm{hr}$. at $37^{\circ}$ the organisms were harvested and cell-free extracts prepared in the usual way. These were examined for decarboxylase activity with the amino acids listed in Table 8. Leucine and valine stimulated formation of decarboxylase readily; isoleucine and norvaline showed less activity. The relative rates of decarboxylation of the five amino acids investigated was independent of whether the cells were grown on broth, or on defined medium with subsequent stimulation by an 'inducer' amino acid. 
Distribution of the decarboxylase. The rates of decarboxylation of valine and leucine by 15 strains of Proteus are given in Table 9. The following facts emerge. The decarboxylase was found in $P$. vulgaris and $P$. mirabilis but not in $\boldsymbol{P}$. rettgeri; this confirms Proom \& Woiwod's (1951) findings. Leucine always showed a rapid initial decarboxylation followed by a decline to a low value; valine always underwent decarboxylation at a steady rate over the $30 \mathrm{~min}$. period of the experiment. In all cases the initial rate of decarboxylation was of the same order for both amino acids.

Table 9. Decarboxylation of valine and leucine by Proteus strains

\begin{tabular}{|c|c|c|c|}
\hline & $Q_{\mathrm{NO}_{2}}^{\mathrm{N}}$ valine & $\begin{array}{c}\mathbf{Q}_{\mathrm{CO}_{2}}^{\mathrm{N}} \text { leucine } \\
\text { (initial) }\end{array}$ & $\begin{array}{c}Q_{C \delta_{2}}^{\mathrm{N}} \text { leucine } \\
\text { (steady) }\end{array}$ \\
\hline P. vulgaris 10 & 14 & 11 & 2 \\
\hline NCTC 4175 & 11 & 16 & $\mathbf{0}$ \\
\hline NCTC 4635 & $\mathbf{5}$ & 5 & o \\
\hline NCTC 4636 & $\mathbf{5}$ & $\mathbf{3}$ & 0.5 \\
\hline P. vulgaris II NCTC 8311 & $\mathbf{5}$ & $\mathbf{5}$ & $0 \cdot 5$ \\
\hline NCTC 8313 & 4 & 6 & $\mathbf{0}$ \\
\hline P. mirabilis NCTC 60 & 8 & 12 & 2 \\
\hline NCTC 4199 & 7 & 7 & 2 \\
\hline NCTC 5887 & 6 & 8 & $\mathbf{2}$ \\
\hline P. mirabilis II NCTC 2100 & 16 & 16 & 4 \\
\hline NCTC 6790 & 13 & 10 & 1.5 \\
\hline NCTC 8309 & 8 & 7 & $\mathbf{3}$ \\
\hline P. rettgeri NCTC 5520 & $\mathbf{0}$ & $\mathbf{0}$ & - \\
\hline NCTC 7474 & $\mathbf{0}$ & $\mathbf{0}$ & - \\
\hline NCTC 7475 & $\mathbf{0}$ & $\mathbf{0}$ & - \\
\hline
\end{tabular}

$Q_{\mathrm{CO},}^{\mathrm{N}}$, values determined using washed suspensions under standard conditions; valine and leucine, $0.03 \mathrm{M}$. No coenzyme added.

Coenzyme requirements. When leucine was added to a washed suspension of Proteus, without added coenzyme, there was a rapid initial reaction which decreased to a slower steady rate after about $10 \mathrm{~min}$. Valine, norvaline, isoleucine, and $\alpha$-amino- $n$-butyric acid however maintained a linear $\mathrm{CO}_{2}$ output for at least $40 \mathrm{~min}$. When pyridoxal phosphate was added, leucine behaved like valine and maintained a fairly linear output (Fig. 3). The concentration of pyridoxal phosphate giving half-maximal velocity was $2 \times 10^{-6} \mathrm{M}$ (Fig. 5). Pyridoxal was equally effective; pyridoxamine required about a tenfold greater concentration. The following were inactive at $10^{-3} \mathrm{M}$; pyridoxin, adenine, adenosine-5-triphosphate, biotin, diphosphopyridine nucleotide (coenzyme I), folic acid, glutathione, calcium pantothenate, riboflavin, thiamine. Pyridoxal phosphate did not accelerate the decarboxylation (by washed suspensions) of any of the other amino acids investigated. It would seem that the washed suspensions might have contained sufficient coenzyme to saturate the apoenzyme when, say, valine was being decarboxylated, but not with leucine. This was borne out by the following observation. 'The decarboxylation of leucine could be stimulated to the degree attained with pyridoxal phosphate by addition to the washed suspension of boiled organisms from the same suspension; but to attain optimal activity, the washed organisms required 


\section{Amino acid decarboxylation in $\mathbf{P}$. vulgaris}

2-5 times their own weight of boiled material. (These experiments were carried out with suspensions prepared from freeze-dried organisms; otherwise, trouble arose from the large 'blank' output of gas which took place when fresh suspensions were allowed to act on boiled organisms). Organisms did not lose activity appreciably on freeze-drying, but after prolonged storage there was some loss of valine decarboxylase activity, and greater (sometimes almost complete) loss with leucine. Activity with both amino acids could be restored by adding pyridoxal phosphate, or, less effectively, by pyridoxal (Table 10).

Table 10. Coenzyme requirements of freeze-dried organisms

\begin{tabular}{|c|c|c|c|}
\hline & \multicolumn{3}{|c|}{ Suspension of freeze-dried organisms } \\
\hline & No addition & $\begin{array}{c}\text { Addition of } \\
\text { pyridoxal, } \\
10^{-4} \mathrm{M}\end{array}$ & $\begin{array}{c}\text { Addition of } \\
\text { pyridoxal } \\
\text { phosphate, } \\
10^{-4} \mathrm{M}\end{array}$ \\
\hline \multicolumn{4}{|l|}{ Expt. 1} \\
\hline$Q_{\mathrm{CO}}^{\mathrm{N}}{ }_{2}$ (valine) & 22 & $\mathbf{2 6}$ & 48 \\
\hline$Q_{\mathrm{CO}}^{N_{2}}$ (leucine) & 4 & $11 \cdot 5$ & 42 \\
\hline \multicolumn{4}{|l|}{ Expt. 2} \\
\hline$\dot{Q}_{\mathrm{C} \delta_{2}}^{\mathrm{N}}$ (valine) & 15 & 25 & 35 \\
\hline$Q_{\mathrm{Co}_{\mathbf{z}}}^{\mathrm{N}}$ (leucine) & $1 \cdot 5$ & 10 & 39 \\
\hline
\end{tabular}

The freeze-dried material had been stored at $0^{\circ}$ for 8 months in Expt. 1, and 2 months in Expt. 2. $Q_{\mathrm{C} \delta}^{\mathrm{N}}$, values determined under standard conditions.

When examined in the absence of added coenzyme cell-free extracts usually showed only slight activity with valine and none with leucine. Activity was restored with respect to both amino acids on adding pyridoxal phosphate. Pyridoxal, pyridoxin, and pyridoxamine, and pyridoxal + ATP were inactive. With whole organisms pyridoxal and pyridoxal phosphate were equally effective in activating leucine decarboxylation; the enzyme which phosphorylates pyridoxal is apparently lost in the preparation of the extracts. Since the decarboxylation of leucine by suspensions was initially rapid, we had to consider whether either apoenzyme or coenzyme were inactivated by the reaction with leucine. Fig. 3 shows that addition of pyridoxal restored the rapid decarboxylation of leucine, even when added after the initial reaction. The apoenzyme was, therefore, apparently fully active. This was investigated further by setting up three Thunberg tubes, each containing $5 \mathrm{ml}$. of a washed suspension of organisms (150 mg. dry wt.) in buffer (pH 6). The hollow stoppers contained, respectively, $2 \mathrm{ml}$. 0.125 M-leucine, $2 \mathrm{ml}$. $0 \cdot 3 \mathrm{M}$-valine, and $2 \mathrm{ml}$. buffer. The tubes were filled with nitrogen and placed in a bath at $37^{\circ}$. The substrates were then added to the suspensions and the reaction allowed to proceed at $37^{\circ}$ for $30 \mathrm{~min}$. The tubes were then cooled in ice, opened, and the organisms centrifuged down in cooled tubes, the supernatant fluids being discarded. The organisms were washed once and resuspended in $5 \mathrm{ml}$. of buffer ( $\mathrm{pH}$ 6). Each suspension was divided into two portions, one of which was examined for decarboxylase activity with both leucine and valine. No difference was found between the three suspensions. The second portion of 
each suspension was boiled and added to a suspension of untreated freezedried organisms. The decarboxylation of leucine was then examined (Fig. 4). The three boiled suspensions activated the freeze-dried suspension equally, showing that they contained similar amounts of coenzyme.

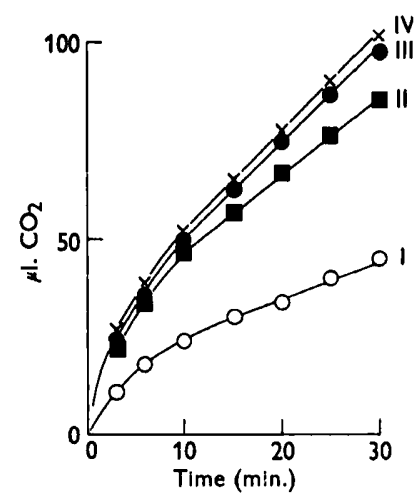

Fig. 4

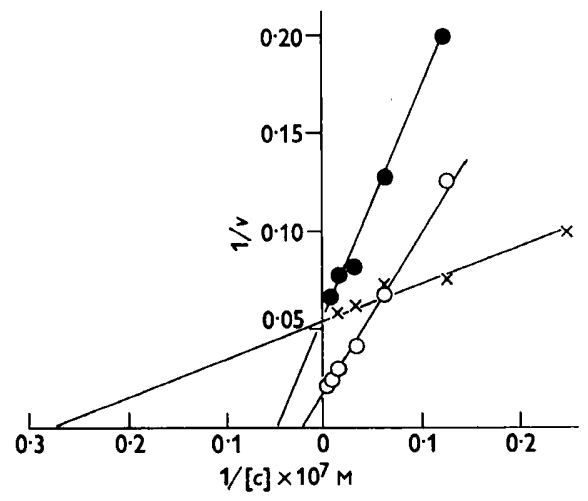

Fig. 5

Fig. 4. Effect of pretreatment of cells on coenzyme content. All manometers contained freeze-dried cells $(20 \mathrm{mg}$.) in main compartment, and leucine (final concentration $0.04 \mathrm{M}$ ) in side-bulb, tipped at $t=0$. The main compartments contained; I, no addition; II, $30 \mathrm{mg}$. cells exposed to buffer (see text) and then boiled; III, $30 \mathrm{mg}$. cells exposed to valine prior to boiling; IV, $30 \mathrm{mg}$. cells exposed to leucine prior to boiling. I thus represents the decarboxylation of leucine without added coenzyme; II, III, and IV show the stimulation provided by the coenzyme present in the variously-treated washed cell preparations.

Fig. 5. Affinity of enzyme for coenzyme. Reciprocal plots (Lineweaver \& Burk, 1934) of rate of decarboxylation $(1 / \mathrm{v})$ against concentration of pyridoxal phosphate $(1 / C)$. Leucine: (intact cells) dots, (cell-free extracts) circles. Valine (cell-free extracts). crosses. $v=Q_{\mathrm{C} z_{2}}^{\mathrm{N}}$, determined under standard conditions with addition of appropriate concentration of pyridoxal phosphate.

Coenzyme affinity. The results so far described suggest that combination of enzyme with coenzyme is weaker when leucine rather than valine is the substrate. This is supported by the experiments with inhibitors (Table 5); the carbonyl-fixatives, which presumably compete with the enzyme for the available coenzyme, inhibited the decarboxylation of leucine more than valine (cf. Gale, 1946). The enzyme-pyridoxal phosphate affinities were therefore determined experimentally (Fig. 5). The $K_{m}$ values obtained were, for the cell-free preparations, $3.5 \times 10^{-7} \mathrm{M}$ for valine decarboxylation and $45 \times 10^{-7} \mathrm{M}$ for leucine. The affinity constant for valine decarboxylation could not be determined in suspensions of whole organisms as the enzyme was already fully saturated: but leucine decarboxylation gave a value of $20 \times 10^{-7} \mathrm{M}$. There does not seem to be any marked tendency for the coenzyme to dissociate on preparation of the cell-free extract, as happens with some dehydrogenases (Green, 1951). The cell-free enzyme appears to bind the coenzyme about ten times more firmly when decarboxylating valine, than when leucine is the substrate. The affinity values found are of the same order, however, as those reported for 
other pyridoxal phosphate systems, e.g. alanine racemase, $2 \times 10^{-6} \mathrm{M}$ (Wood \& Gunsalus, 1951); tryptophanase, $2 \cdot 1 \times 10^{-6} \mathrm{M}$ (Wood, Gunsalus \& Umbreit, 1947); transaminase (mammalian muscle), $5 \times 10^{-6} \mathrm{M}$ (O'Kane \& Gunsalus, 1947); tyrosine decarboxylase, $2 \times 10^{-8} \mathrm{M}$ (Umbreit \& Gunsalus, 1949).
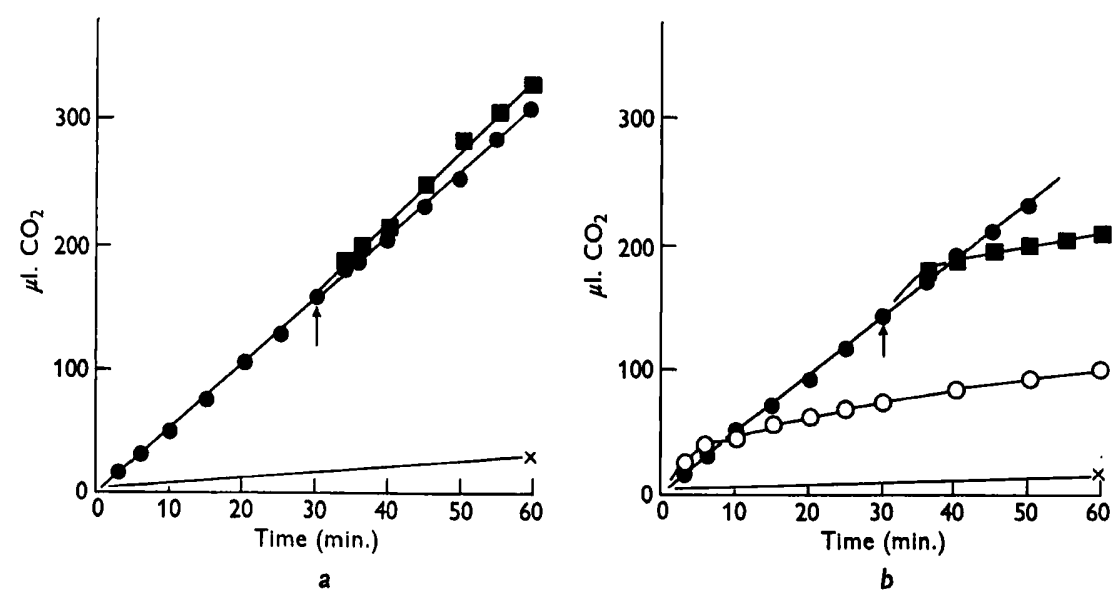

Fig. 6. Effect of leucine on valine decarboxylation by intact cells : $(a)$ in presence of pyridoxal $\left(10^{-4} \mathrm{M}\right) ;(b)$ in absence of added coenzyme. No-substrate control, $\times-\times$; valine (final concn., $0.04 \mathrm{M}$ ) added at $t=0$, - ; valine at $t=0$, leucine (final concn. $0.04 \mathrm{M}$ ) at $t=30 \mathrm{~min}$., $\square \longrightarrow$; leucine at $t=0, \mathrm{O}-\mathrm{O}$.

Competitive inhibition by coenzyme dissociation. Leucine itself has a greater affinity for the system than valine. This leads to the curious situation illustrated by Fig. 6 . In Fig. $6 a$, valine was added to a suspension of organisms at $t=0$ in the presence of excess coenzyme $\left(10^{-4} \mathrm{M}\right.$ pyridoxal) and the decarboxylation followed its usual linear course. At $t=\mathbf{3 0} \mathrm{min}$., leucine was added from a second side-bulb (buffer added in the control) without causing any significant alteration in the rate of $\mathrm{CO}_{2}$ output. When the experiment was repeated (Fig. 6) without addition of pyridoxal, the result was quite different. During the first $30 \mathrm{~min}$. there was the usual linear decarboxylation of valine; but, on adding leucine at $t=30 \mathrm{~min}$., the rate of $\mathrm{CO}_{2}$ evolution rapidly decreased to a slower rate more comparable with that obtained when leucine alone was being decarboxylated (cf. lower curve). The effect was more striking when a cell-free enzyme preparation was used. In the presence of $10^{-6} \mathrm{M}$-pyridoxal phosphate valine was decarboxylated rather below its optimal rate, leucine not at all. But when leucine was added to a preparation already decarboxylating valine, the reaction was completely inhibited within a few minutes (Fig. $7 b$ ). No such inhibition was seen when $10^{-4} \mathrm{M}$-pyridoxal phosphate was used; this concentration suffices to saturate either leucine or valine decarboxylation. In these experiments it seems that leucine, by virtue of its higher affinity, has displaced valine from the enzyme. But, when decarboxylating leucine, the enzyme appears to loosen its grip on the coenzyme. When the latter is not present in excess, the decarboxylation of both amino acids is partially or completely inhibited. 

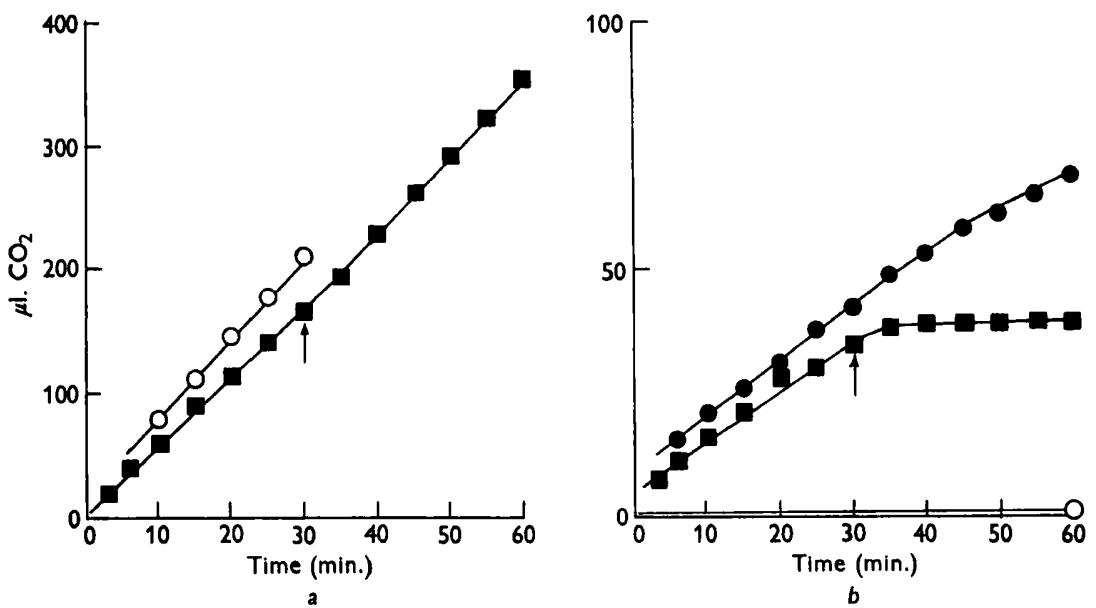

Fig: 7. (a) Effect of leucine on valine decarboxylation by a cell-free preparation in presence of excess $\left(10^{-4} \mathrm{M}\right)$ pyridoxal phosphate. $O-O$, decarboxylation of leucine; $\square-\square$, decarboxylation of valine, leucine added at $t=30 \mathrm{~min}$. (b) The same experiment but with limiting concentration $\left(10^{-6} \mathrm{M}\right)$ of pyridoxal phosphate. $\mathrm{O}-\mathrm{O}$, leucine de. carboxylation (negligible); --O, decarboxylation of valine: $\square-\square$, decarboxylation of valine inhibited by addition of leucine at $t=30 \mathrm{~min}$.

\section{DISCUSSION}

We must first consider whether a single enzyme of broad specificity is involved, or a number of highly specific enzymes. It will be noted that valine and leucine decarboxylase activities ran approximately parallel for the series of organisms recorded in Table 9 , and that both showed similar sensitivity to a variety of inhibitors and destructive agents (Table 5), except that leucine decarboxylation was more sensitive towards the carbonyl fixatives. More crucial evidence however is provided by the following observations.

(1) When the cell-free extracts were offered two amino acids simultaneously, in none of the six combinations tested was a rate of $\mathrm{CO}_{2}$ output found greater than that which could be achieved with one substrate alone. This was true whether the substrates were added simultaneously (Table 1) or sequentially (Figs. 6, 7); whole organisms and cell-free preparations behaved alike in this respect.

(2) The decarboxylase system is adaptive (inducible) and is not formed in a simple defined medium containing no amino acids. The relative activity towards the various potential substrates does not depend upon which of them is used as inducer. Thus, the decarboxylase activity for leucine is still greater than for valine, even in extracts prepared from organisms in which the system has been induced by valine.

(3) The phenomenon of competitive inhibition by coenzyme dissociation (Figs. 6, 7). If we assume that valine and leucine decarboxylation are catalysed by separate enzymes we must interpret these results as being due to the leucine enzyme pulling the coenzyme away from the valine decarboxylase, and this is hard to reconcile with the fact that it is the valine system which has the 


\section{Amino acid decarboxylation in $\mathbf{P}$. vulgaris}

greater affinity for the coenzyme (Fig. 5). The alternative explanation, that a separate leucine enzyme acts also as a competitive inhibitor of valine decarboxylation, seems unlikely in view of the failure of leucine to inhibit valine decarboxylation when adequate coenzyme is available. These results are, however, consistent with the decarboxylation of valine and leucine being due to a single enzyme.

Although the bacterial amino acid decarboxylases described by other workers (Gale, 1940; Dewey et al. 1954) are highly specific enzymes, it seems difficult to maintain that we are dealing with a number of separate and specific enzymes here, in view of the failure to obtain an additive effect when more than one substrate is offered, the quantitatively non-specific action of the inducers, and the inhibition by leucine in the presence of low concentration of coenzyme. We recognize, however, that it is never possible to prove that a series of reactions is not due to separate enzymes. But we consider that the most reasonable interpretation of these results is that at least valine and leucine are decarboxylated by a common enzyme, which is possibly also responsible for the breakdown of isoleucine, norvaline, and $\alpha$-amino- $n$-butyric acid. The existence of separate decarboxylases for these last two amino acids, which are not normally found in biological materials, would be unlikely on a priori grounds. The position of phenylalanine is not clear since the decarboxylation of the amino acid is too slow for convenient study.

Table 11. Comparison of properties of certain amino and decarboxylases

\begin{tabular}{|c|c|c|c|}
\hline & \multicolumn{3}{|c|}{ Decarboxylase } \\
\hline & $\begin{array}{l}\text { Glutamic acid } \\
\text { tyrosine, etc. } \\
\text { (Gale, 1946) }\end{array}$ & $\begin{array}{c}\text { Diamino- } \\
\text { pimelic acid } \\
\text { (Dewey, et al. } \\
\text { 1954) }\end{array}$ & $\begin{array}{l}\text { Valine, } \\
\text { leucine, } \\
\text { etc. }\end{array}$ \\
\hline $\begin{array}{l}\text { Nature of side-chain of } \\
\text { substrate(s) }\end{array}$ & Polar & Polar & Non-polar \\
\hline $\begin{array}{l}\text { Optimum pH for enzyme } \\
\text { action }\end{array}$ & Very acid & Neutral & Neutral \\
\hline $\begin{array}{l}\text { Optimum pH for enzyme } \\
\text { formation }\end{array}$ & Acid & Variable & Neutral \\
\hline Optimum age of culture & Mature & Variable & Young \\
\hline $\begin{array}{l}\text { Maximal attainable } \\
\text { activity }-Q_{0}^{N},\end{array}$ & $100-1000$ & $5-10$ & Up to 30 \\
\hline $\begin{array}{l}\text { Substrate affinity } \\
\text { approximate Ks }\end{array}$ & $10^{-3} M$ & $10^{-8} M$ & $\begin{array}{l}\text { Valine, } 0.03 \mathrm{M} \\
\text { leucine, } 0.01 \mathrm{M}\end{array}$ \\
\hline
\end{tabular}

The bacterial amino acid decarboxylases hitherto described fall into two groups; one includes the six enzymes described by Gale (1946) which attack, respectively, glutamic acid, lysine, ornithine, histidine, tyrosine and arginine; the other comprises the diaminopimelic acid decarboxylases of Dewey et al. (1954). These enzymes are compared in Table 11 with the system now under discussion. Gale (1946), seeking a possible function for the decarboxylases, suggested that they might constitute a 'neutralization' mechanism; their formation and action at acid $\mathrm{pH}$ values would lead to the production of strong bases which would raise the $\mathrm{pH}$ to a value more suitable for growth. This 
suggestion is inapplicable to the system described in this paper, and we can offer no suggestion as to the part it plays in the metabolism of the cell.

The relationship of the enzyme to its coenzyme calls for some comment. The affinity of the enzyme for pyridoxal phosphate appears to depend upon the nature of the substrate undergoing decarboxylation, being greater with valine than with leucine. This is an interesting situation for which we are not aware of any precedent. It can, however, be reconciled easily with current views on enzyme action. If we assume that decarboxylation involves the formation of a complex V-E-C or $\mathrm{L}-\mathbf{E}-\mathrm{C}$, where $\mathrm{V}$ and $\mathrm{L}$ are valine and leucine, $\mathrm{E}$ the enzyme and $C$ the coenzyme, then we can see that during valine decarboxylation the dissociation of the coenzyme will be represented by the reaction $\mathrm{V}-\mathrm{E}-\mathrm{C} \leftrightharpoons \mathrm{V}-\mathrm{E}+\mathrm{C}$, which in the case of leucine will become $\mathrm{L}-\mathrm{E}-\mathrm{C} \leftrightharpoons \mathrm{L}-\mathrm{E}+\mathrm{C}$; and there is no a priori reason why the equilibrium constants of these two reactions should be the same.

One point remains to be explained: why should the decarboxylation of leucine start rapidly and then decline? We can only suggest that the loss of coenzyme by dissociation is a relatively slow process. On addition of leucine, several minutes elapse before the coenzyme has left the enzyme surface, and that during this period it is still able to catalyse the decarboxylation. This is consistent with the observation that in some other pyridoxal phosphate systems, the combination of coenzyme and apoenzyme proceeds quite slowly.

We are deeply grateful to Professor R. A. Morton, F.R.S., for his interest, encouragement and advice; to the Ministry of Education for a grant to one of us (C.R.S.) and to the Medical Research Council for a grant to defray expenses.

\section{REFERENCES}

Anon (1950). Organic Reagents for Organic Analysis, 2nd ed., p. 120. London: Hopkin and Williams.

Bernheim, F., Bernheim, M. L. C. \& Webster, M. D. (1935). Oxidation of certain amino acids by 'resting' Bacillus proteus. J. biol. Chem. 110, 165.

Bremner, J. M. \& Kenten, R. H. (1951). Paper chromatography of amines. Biochem. J. 49, 651.

Chargaff, E. \& Sprinson, D. B. (1943). Studies in the mechanism of deamination of serine and threonine in biological systems. J. biol. Chem. 151, 273.

Conway, E. J. (1947). Microdiffusion Analysis and Volumetric Error, 2nd ed. London: Crosby, Lockwood and Son.

Demeny, L. (1931). Arylsulphonalkylamides. Rec. Trav. chim. Pays-Bas, 50, 51.

Dewey, D. L., HoAre, D. S. \& Work, E. (1954). Diaminopimelic acid decarboxylase in cells and extracts of Escherichia coli and Aerobacter aerogenes. Biochem. J. $58,523$.

Ekladius, L. \& King, H. K. (1956). The valine/leucine decarboxylase of Proteus: a study in coenzyme dissociation. Biochem. J. 62, 7 p.

EkLADIUS, L. \& KING, H. K. (1957). Estimation of lower aliphatic amines. Biochem. J. 65, 128.

GaLE, E. F. (1940). The production of amines by bacteria. I. The decarboxylation of amino acids by strains of Bacterium coli. Biochem. J. 34, 392.

Gale, E. F. (1941). Production of amines by bacteria. 4. The decarboxylation of amino acids by organisms of the groups Clostridium and Proteus. Biochem. J. $35,66$. 


\section{Amino acid decarboxylation in $\mathbf{P}$. vulgaris}

Gale, E. F. (1946). The bacterial amino acid decarboxylases. Advanc. Enzymol. 6, 1. Green, D. E. (1951). The cyclophorase system of enzymes. Biol. Rev. 26, 410.

Johnson, T. B. \& Guest, H. W. (1909). Researches on amines: synthesis of methylphenylethylamine. Amer. chem. J. 42, 340.

Kallio, R. E. \& Ponter, J. R. (1950). Metabolism of cystine and cysteine by Proteus vulgaris and Proteus morganii. J. Bact. 60, 607.

KING, H. K. (1953). The decarboxylation of valine and leucine by washed suspensions of Proteus vulgaris. Biochem. J. 54, xi.

KING, H. K. \& AleXANDER, H. (1948). The mechanical destruction of bacteria. J. gen. Microbiol. 2, 315.

Lineweaver, H. \& Burk, D. (1934). The determination of enzyme dissociation constants. J. Amer. chem. Soc. 56, 658.

McIlwain, H. (1948). Preparation of cell-free bacterial extracts with powdered alumina. J. gen. Microbiol. 2, 288.

Marckwald, W. (1899). Die Stereochemie des Stickstoffes. Ber. dtsch. chem. Ges. 32, 3508.

Meister, A., Sober, H. A. \& Tice, S. V. (1951). Decarboxylation of aspartic acid to $\alpha$-alanine. J. biol. Chem. 189, 577.

O'Kane, D. E. \& Gunsalus, I. C. (1947). Resolution and purification of glutamicaspartic transaminase. J. biol. Chem. 170, 425.

Papworth, D. S. (1951). The Nitrogen Metabolism of Bacteria. Thesis, Liverpool.

Proom, H. \& Worwod, A. J. (1951). Amine production in the genus Proteus. J. gen. Microbiol. 5, 930.

Stumpf, P. K. \& Green, D. E. (1944). l-Amino acid oxidase of Proteus vulgaris. J. biol. Chem. 153, 387.

TARR, H. L. A. (1933). The anaerobic decomposition of $l$-cystine by washed cells of Proteus vulgaris. Biochem. J. 27, 759.

Umbreit, W. W. \& Gunsalus, I. C. (1949). Codecarboxylase not pyridoxal-3phosphate. J. biol. Chem. 179, 279.

WADEKIND, E. (1909). Über das Verhalten ungesättigter Gruppen in quartären Ammoniumsalzen und tertiären Sulphonamiden. Ber. dtsch. chem. Ges. 42, 3939.

WillaARD, W. L. \& Jones, M. Z. (1940). Optical properties of phenylthiourea derivatives. J. Amer. chem. Soc. 62, 2876.

Wood, W. A. \& Gunsalus, I. C. (1951). d-Alanine formation: a racemase in Streptococcus faecalis. J. biol. Chem. 190, 403.

Wood, W. A., Gunsalus, I. C. \& Umbreit, W. W. (1947). Function of pyridoxal phosphate. Resolution and purification of tryptophanase of Escherichia coli. J. biol. Chem. 170, 313.

(Received 26 April 1957) 